\title{
Crime and the Road: A Survey of Sixteenth-Century Travel Journals
}

\section{LUIGI MONGA}

\begin{abstract}
A man was going down from Jerusalem to Jericho, and he fell among robbers, who stripped him and beat him, and departed, leaving him half-dead (Luke 10:30).
\end{abstract}

Summary: This article is a journey through the lesser known travel diaries of the sixteenth and seventeenth centuries. Its intent is to underline the occurence of violent images along the European roads, particularly in Italy, Spain, France, and England. Criminality, danger, and violence are all common phenomenons in the Renaissance. Travelling allows one to discover the foreign but not without hardship: avoiding bandit and corsair traps, travellers are then welcomed at the entrance of the cities by gallows adorned with corpses and are entertained, if they so desire, with executions and autodafés. Travel literature depicts a violent and bloody Renaissance.

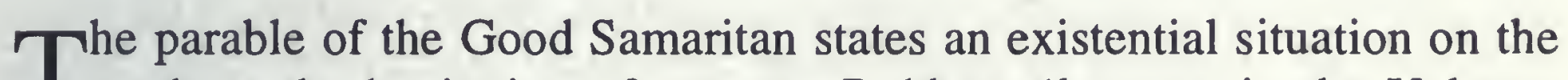
1 roads at the beginning of our era. Robbers (latrones in the Vulgate, $\lambda \eta \sigma \tau \alpha l$ in the Greek Septuagint version) have been a common encounter on isolated stretches of road in Biblical times, so common, in fact, that the Bible uses them in a striking simile: the prostitutes lurk at passers-by just as robbers awaiting their prey ("insidiatur in via quasi latro," Prov 23:28; "expectans eos quasi latro in solitudine," Jer 3:2). ${ }^{1}$

And when Paul detailed all the dangers he suffered while preaching the Gospel, he uses the same word: "in danger from rivers, danger from robbers, 
danger from my own people, danger from Gentiles, [...] dangers in the wilderness, danger at sea..." (2Cor 11:26).

The roads of the ancient world were crowded with strange travellers; ${ }^{2}$ predators and preys walked side by side. Throngs of beggars dressed in rags and pseudo-monks begging on behalf of a god have been commonplace on the roads in Roman times. ${ }^{3}$ In the Golden Ass the pseudo-Lucian wrote of fake paupers who carried the goddess Syria, begging for food and money "through fields and villages," mutilating themselves to scare naive peasants into giving generously $(35,37)$. Vagrancy of this sort was frequent in the first centuries of Christianity. Monks and pseudo-monks, taking advantage of Christ's order to provide for the indigent, abused the charity and naiveté of good people. There were even some people on the road like the Circumncelliones $^{4}$ (circuitores), a fourth-century sect whose suicidal adepts roamed the northern African area, according to Philasterion, ${ }^{5}$ waiting for passers-by, begging to be killed by them ("quos inveniunt in via cogunt ut interficiantur ab illis dicentes se desiderare pati martyrium"). Augustine mentions this entire crowd with horror:

Tam multos hypocritas sub habitu monachorum usquequaque dispersit [callidissimus hostis], circumeuntes provincias, nusquam missos, nusquam fixos, nusquam stantes. [...] Alii membra martyrum, si tamen martyrum, venditant, alii fimbrias et phylacterias suas magnificant, ... et omnes petunt, omnes exigunt, aut sumptus lucrosae egestatis, aut simulatae praetium sanctitatis. ${ }^{6}$

In the Middle Ages the councils tried unsuccessfully to eradicate this "tradition of [road] crime," as Camporesi has called it, ${ }^{7}$ but it would spread eventually beyond the Mediterranean area. ${ }^{8}$ There is an overwhelming streak of morbid curiositas in the medieval world; in spite of monastic rules, church councils, and imperial decrees blasting this sin, crowds of monaci vagantes join professional beggars (cerretani) moving about Europe without a specific goal. Throngs of people roam the roads: merchants, colporteurs, vagabonds, itinerant monks, runaway religious, poets and troubadours, teachers and college students, courriers, healers, real pilgrims, gypsies, craftsmen, parasites.

"La mobilité des hommes du Moyen Age a été extrême, déconcertante," wrote Jacques Le Goff. ${ }^{9}$ And a thirteenth-century Italian poem, the "Detto del gatto lupesco," underscores the unholy mix of that crowd: "... uomini vanno / ki per prode e ki per danno, / per lo mondo tuttavia." 10 Piero Camporesi detailed this world: 
dei giudei erranti e maledetti (e naturalmente dei loro falsificatori), dei mendicanti veri e dei mendicanti falsi (la gueuserie), delle congreghe di ciechi, degli storpi, degli attratti, dei lebbrosi, dei mercenari e dei soldati che andavano alla guerra o che dalla guerra ritornavano (o dicevano di ritornare), degli scampati dai pirati e dagli infedeli, dei servi fuggiaschi ..., i fuggitivi colpiti dal bando (i bannis), gli uomini dediti alla rapina e al furto (caïmans, marauds), le bande di soldati sbandati che vivevano alle spalle della gente dei campi (belîtres), gli essorillés (malfattori e delinquenti recidivi che avevano avuto mozzate le orecchie dal carnefice), "larrons, mendiants, espieux de chemin, ravisseurs de femmes, violeurs d'Église, tireurs à l'oye, joueux de faulx dez, trompeurs, faux monnoyeurs, malfaicteurs et autres associez, récepteurs et complices ..."; e poi autentici disoccupati, affamati, gente senza un vero mestiere. E infine, a partire dai primi decenni del Quattrocento, gli zingari; venivano poi gli artigiani e i lavoratori itineranti: tessitori, calderai, seggiolai, arrotini, impagliatori, muratori, i maestri e gli apprendisti delle arti mobili, e tutta la schiera innumerevole degli artigiani stagionali che abbandonavano le loro terre e le loro vallate per esercitare il mestiere in stagioni brevi - lunghe in altri paesi e contrade, ed ogni gruppo col proprio linguaggio "corporativo" o gergo segreto (la lingua occulta), con gli abiti-divisa (o con gli abiti-travestimento), coi suoi santi, le sue cantilene e salmodie, le sue pentole, i suoi sogni; e le strade con le taverne, le locande invitanti sotto l'insegna e il mazzo d'agrifoglio, i ponti coi loro custodi, le porte delle "terre," gli ospizi, le abbazie, i conventi, i cenobi, le foresterie, gli ospedali dei poveri e dei pellegrini.

This libido currendi could be considered an essential aspect of the plot of the chansons de geste and medieval romance. It is an aberration that enters even the pilgrimages, "superstitiosus et immodicus quorundam affectus," according to Erasmus, 12 "otieux et inutilles voyages," says Rabelais (Gargantua, XLV), harmful and contrary to the most basic laws of economics and household propriety.

If, according to Emerson, "travelling is a fool's paradise," for "the rage of travelling is a symptom of deeper unsoundness," 13 nonetheless, travel for travel's sake has always been popular. Wandering can even be a way to open one's ears and relax one's spirit while looking for the elusive Tao of oriental philosophy. ${ }^{14}$

Meanwhile, sixteenth-century Europe witnessed the urbanization of a faceless mass of disenfranchised people,

esa masa constituida a base de moriscos, campesinos emigrantes (sin tierras) que fuían a la ciudad, desempleados de toda laya, esclavos negros y blancos (moros apresados), esclavos y esclavas "criollos" (negros nacidos en América y reimportados), libertos, vagabundos, mendigos (verdaderos - los menos - y simulados - los más -), rufianes, matones, pícaros, ladrones, prostitutas, chulos y guardianes ("padres"), oficiales de mancebías (hombres y mujeres, reglamentados y aprobados por el Ayuntamiento). ${ }^{15}$ 
This mass movement developed into a literary representation of the life and adventures of picaros roaming the world while crossing various social classes. ${ }^{16}$ The following inventory by Cervantes brings back Augustine's catalog of vagantes as a constant in Western civilization:

¡O pícaros de cocina, sucios, gordos y lucios; pobres fingidos, tullidos falsos, cicateruelos de Zocodover y de la plaza de Madrid, vistosos oracioneros, esportilleros de Sevilla, mandilejos de la hampa, con toda la caterva innumerable que se encierra debajo deste nombre picaro! ${ }^{17}$

Banditism is a wide-spread phenomenon in the Renaissance. It is not necessarily typical of South-European areas, as the word "banditti" has come to imply in the English lexicon. ${ }^{18}$ Antonio De Beatis notes in Germany (1517) "lochi fortissimi dove se retirano molti rubaldi"; he adds that "per tucto habiamo trovato rote et forche infinite ... de modo che da ciò se comprende che se fa gran justitia, quale non è dubio in tali paesi sii necessariissima"19. Coryate "observed in a great many places, on both sides of the Rhene, more gallowes and wheeles betwixt Mentz [Maintz] and Colen [Cologne], than ever [he] saw in so short a space in all [his] life." ${ }^{20}$ It is a topos which recurs very often in Coryate's journal. He is shocked by "the dolefull and lamentable spectacle" of "bones and ragged fragments of clothes" of an executed assassin: his "bones [...] miserably broken asunder and disperses abroad upon the wheele in diverse places" (I, 196). Every time Coryate was told of "false knaves" lurking in a forest "under trees and shrubbes, and suddenly set upon travellers and cut their throates," he remembers the "stately gallowes" usually located outside towns $(\mathrm{I}, 159,160)$; he even notices "the fayrest gallowes that [he] ever saw, [...] which consisteth of fourteene fair pillars of free-stone" (I, 170). Jean-Jacques Bouchard mentions parenthetically that outside Moulins "l'on voit un gibbet où il y avoit plus de deux douzaines de pendus." 21 In Switzerland, according to a Venetian traveller, "there were gallows every half league"; so elegant and well-built gallows, in fact, that "one would die on them with a certain nobility."22 In Spain hanging corpses were a commonplace: "et perhò in Spagna si camina tanto sicuro quanto in altro loco." 23 In 1553 Charles Estienne's Guide des chemins de France faithfully mentions the numerous bandits' nests on the French roads, and in 1652 John Evelyn has a fearful encounter with robbers in good old England. ${ }^{24}$ Ten years later (1665), abate Sebastiano Locatelli sees three bandits in the forest of Fontainebleau, an area "pien[a] d'assassini, particolarmente quando il re è in quella città." 25 This should dispell not only the myth of southern banditism, but also that its 
development is caused mainly by social or political upheaval. Locatelli is specific on this point: the bandits are there because the king's presence draws many rich people to his château. It is implied that there is little fear of the king's guards among the "assassini": they are fearsome individuals, admits Locatelli, tongue-in-cheek. Scared witless, the small group of travellers prays the Rosary ("tutto il rosario di quindici poste, con l'uffitio della Madonna"), and even the vetturino joins in the prayers, "che non fu poco," which is a rare event in itself, since "simil canaglia" (the vetturini) is not known for its devotion ... (p. 191).

Southern Italian banditism was (one could even venture to say that still is) an interesting social phenomenon. Arising in the late Middle Ages from the political vacuum that existed in the areas between the State of the Church and its neighbors, the local briganti were able to cross the border with impunity whenever the pope or the viceroy or the duke threaten to pursue and prosecute them. Thomas Hoby, on his way to Sicily, "owt of Englishmenne's company for the tung's sake," has to cross many woods "verie jeapardous to passe ... for the presence of banisshed men" waiting for their pray, "and many a man is there robbed and slaine in the yere by them." 26 Fynes Moryson offers a clear account of the reasons that produce such a situation:

The Italians in generall are the most strict in the courses of Justice, without which care they could not possiblie keepe in due order and awe the exhorbitant dispositions of that nation, and the discontented myndes of their subjects. Yet because only the Sergiants and such ministers of Justice are bound to apprehend Malefactours, ... and because the absolute Principalities are very many and of little circuite, the malefactors may easily fly out of the confines, where ... they finde safe retreat. ${ }^{27}$

Sometimes these briganti functioned almost as toll-keepers, simply requesting (or ... forcing) the travellers to pay a token sum in order to be allowed to pass through. They are sometimes perceived almost as tax collectors, the infamous doganieri whose exhorbitant requests are as evil as highway robbery. ${ }^{28}$ The lore of the good-hearted bandito stems from this environment. ${ }^{29}$ In 1588 , according to G. B. Manso, Tasso's first biographer, the Italian poet was stuck in Mola, on his way from Rome to Naples, by the presence of the famous Marco di Sciarra, "il quale è in questi confini con gran numero di banditi, come dicono; e ieri uccisero molti uomini di questa terra, altri condussero prigioni." Knowing that the famous poet had been inconvenienced by his men, the bandito offered him free passage "e albergo per lo viaggio, e tutto ciò che da lui imposto gli fosse."30 
We should not be totally surprised to find only indirect allusions to encounters with bandits in the journals of Renaissance travellers. If the bandit, by definition, robs and kills his victims, there is a small chance that the travellers who have fallen prey to such a dastarly individual can live to write their memoirs for the enjoyment of the reader. Dead people do not write travel journals. On the other hand, travellers, as Montaigne did on the mountains between Sarzana and Genoa in 1582, were known to select an alternative route to avoid the encounter of bandits. ${ }^{31}$ If the travellers are successful at avoiding the bandits, it is obvious that they are not going to relate any evil encounter in their travelog. This is why very few travellers can attest to a direct experience of highway criminals. Most travel accounts relate only fears, hearsay, ${ }^{32}$ encounters (true or imagined) of the "second kind" (a quick glance from a safe distance), and, more often, the dead bodies of robbers hanging from the gallows. As the travellers' collective imagination is built up in the inn, around the table or the fireplace, everyone adds a personal touch: they all find the threat of bandits an absolutely exciting topic, a stimulating thrill in an otherwise bland trip, an affabulation that makes the tellers feel a bit heroic.

The most objective accounts of travellers encountering bandits is probably to be found in the Jesuits' letters to their superiors. The road from Rome to Naples is, as expected, the most dangerous. In January 1561 Fr. Francesco Granata wrote to the General, nonchalantly, that the vetturino ran away as soon as he saw the ladri. Fortunately, a Neapolitan gentleman, more courageous, faced the bandits, and they withdrew. Many horror stories can be found in the Archives of the Jesuits in Rome (Scaduto 337-339). ${ }^{33}$

Travelling in the Renaissance was not for the faint-hearted. François Villon's well-known poem, "La Ballade des pendus," is definitely a vivid reminder of the gory scenes that were so common on the roadside. A Milanese merchant who crossed the London bridge after the infamous May Rebellion of 1517 noticed a row of severed heads of the rebels stuck on lances and lining both sides of the bridge (p. 88)!

Among other sights, a public execution of criminals was indeed a great pastime. On January 11, 1581, Montaigne offers in his journal a comparative study of French and Italian public executions, while describing the torture and killing of the notorious Catena, "un fameux voleur et Capitaine des bandits, qui avoit tenu en crainte toute l'Italie et duquel il se comptoit des meurtres enormes" (pp. 97-98). Abate Busino describes at length a public execution in London. As a priest, he was not allowed by the Church's Canon 
Law to "enjoy" the sadistic entertainment of the gallows, and we are shocked to see that this otherwise good man shows no compassion for the small-time thiefs that are hanging "just like a bunch of dead thrushes." In mid-seventeenth-century Paris, Sebastiano Locatelli, another Italian priest, witnessed a most cruel execution which he describes in great detail. ${ }^{34}$ The Faubourg Saint-Honoré was the most fashionable place for public executions, and people enjoyed the free show.

As a footnote, let us not forget that the guillotine was not the invention of the infamous French Docteur Guillotin, as all encyclopedias would keep repeating. In 1645, John Evelyn witnessed a public execution in the Piazzetta near San Marco, just next to the Biblioteca Marciana: "I saw a wretch executed, who had murther'd his master, for which he had his head chop'd off by a axe that slid down a frame of timber, betweene the two tall columns in St. Marcs Piazzo at the sea brink; the executioner striking on the axe with a bettle [a heavy mallet], and so the head fell of the block" (p. 459).

Security on the road, however, was not totally assured: most travellers complained about the uncertainty of reaching their goal and the dangers of bad encounters. So much for death penalty as a crime deterrent. Fearful of all potential dangers, our traveller still brings with him a set of pistols: even a good priest has his pair, and sometimes it is proven useful, at least to scare some drunkards in a far-away inn. ${ }^{35}$ Weapons, however, are not normally allowed into cities: pistols have to be left at the gates of a city. Morcroft was not admitted in Genoa before he surrendered his weapons to the guards at the gate, "yet many gentlemen and others wear their daggers behind them, whereby they take their opportunity to revenge themselves of those that have done them but a seeming injury." 36 In Genoa, Francesco Rucellai and his party leave their pistols at the city door. ${ }^{36}$ It is often necessary, however, to have them ready, next to one's own bed at night, particularly in rural inns:

... smontati giù dal letto e preso le nostre pistole che a capo di esso stavano, accorremmo al romore, non sapendo s'erano quelli della terra ... o che cosa fussi, trovammo che un soldato briaco haveva tirato una pistolettata senza colpire però al nostro credentiere, il quale gli rispose con una carabina ... (p. 56).

Visiting Valencia, the secretary of Antonio Tiepolo, Venetian ambassador to the court of Philip II, wrote in 1572:

In questa città vi sono tre nobilissime cose: un hospital de' pazzi, nel quale ne sono infiniti, ma governati per verità con grandissima diligenza, ... il locco delle donne publiche, serrato di muro con 300 casete dentro, piene di belle et publiche meretrici, et sane, ... [e] una forca fuori della città, capace di mille ladroni, e di continuo è molto ben fornita. 
Sex, madness, and violence: what else do we need to make great reading? The encounter with bandits ${ }^{37}$ was a very real danger for the traveller, and that in spite of numerous gallows scattered in every countryside, often with rotting corpses slowly twisting in the wind. The bandits, in Rucellai's case, were regular soldiers, moonlighting, we could say, between Parma and Piacenza: "si vedevano ... fanterie acquartierate che erono quelli che assassinavano $\mathrm{i}$ viandanti, havendo questo medesimo giorno ammazati dua contadini" (p. 13). Orazio Busino, travelling in Spain in 1619, writes: "[...] andassimo [...] per paese inculto e sterile, senza veder che alcune poche case lontane, onde hanno molta comodità li ladri di farsi sentire, et ve ne sono assai, con tutto il rigor della giustitia, et se ne vedono molti appesi et molte sepolture de' assassinati da loro" (p. 142). And further on, in Castellric, between Barcelona and the French border, the Italian travellers see "molte teste di ladri, et per il camino moltissime donne appiccate per streghe" (p. 145).

The retribution for homicide (an eye for an eye) does not, however, stop the explosion of crime. In this respect it appears that even the public spectacle of cruel executions is not a deterrent. On one hand, banditism is endemic in some rural areas of Europe, particularly in the desert expanses of Spain, whose coastline was also often attacked by Turkish pirates. ${ }^{38}$

... giongemo a Sigier, villa grossa alla marina, con molto pericolo di fuste et bandolieri, perché pocco prima ne erano state scoperte quattro poco discoste et la notte inanti li assassini haveano saccheggiata una casa et amazzato il padron di essa, lontano un miglio da questa villetta (Antonio Tiepolo, 26 March 1572).

But the show of the corpses of highway robbers, hanging from trees, is such a common sight on the road, that a priest mentions it without much ado, even with a smirk. Near Orléans, Busino sees "un bosco da una parte et l'altra della strada, appresso la quale vedemmo quattro ladroni attaccati a certi roveri, freschi freschi." 39

On the other hand, local protection offers bandits safe haven, as Antonio Tiepolo experienced in 1571 between Tortosa and Barcelona:

qui pigliammo scorta di 25 buoni archibuggieri per il pericolo di bandolieri (che sono assassini) fino in Barcelona, li quali sogliono andar 50 et 50, et in alcuni luoghi vicini a Saragosa 200 et 300; assassina et splogliano senza far altro danno nella vita tutti li passagieri che trovano, aspettandoli in passi sì difficili che non si possono diffendere né li avanza speranza di fuggire, né può il re, con tutto che habbia usato gran diligenza rimediar a questi disordini, perché li capi de questi bandolieri sono li capi del regno 
d'Aragon et di Cathalogna, li quali hanno dipendenze di parentådo o amititia nel Maggior Consiglio di questi regni (20 March 1572).

In every country there are strict rules regarding protecting travellers against bandits. One of the most revealing is the series of ordonnances issued by the États de Blois in 1576, which held the lord and the inhabitants of the closest village responsible for any crime committed by bandits in their territory. It must have been obvious to the legislator that there was collusion (or at least a cozy relationship) between the locals and the bandits: severe fines and the loss of financial privileges were the penalty for not finding the culprits of road crimes. ${ }^{40}$

We have delt mainly with security on the road, recording examples of violent crime. Theft is also very common, and is mentioned parenthetically as a necessary evil, albeit a minor one. After someone stole from his purse with money and document, in the middle of the night in an inn near Gaillon, a furious De Beatis compares the honesty of the Germans and the French and concludes:

Et come de Thodeschi et Fiamminghi, quali più volte lassandose per rescordo del repostero alcun pezzo de argento in loro hosterie ce li restituevano gratiosamente, ho scripto assai bene, essendo con effecto grandissima lealità et fede in tucta quella gente etiam in poverhomini et disgratiati, che è tanto più laudabile, cusì de Franciosi, havendo da essi ricevuto tal burla, ... La plebe è tanto vile, pultrona et viciosa quanto homo si possa pensare (p. 128).

But this is small change, and even in the age of global tourism we have accepted this crime just as a small inconvenience which affects every country in the world, with the exception, perhaps, of Singapore, so well-organized a society where even jaywalking and gum chewing are punishable offenses.

\section{Vanderbilt University}

\section{Notes}

1. This last quote is commonly translated as "as an Arab in the desert," which, although politically incorrect, still conveys the sense of dangerous enmity that a robber represented for a Jewish traveller.

2. See the section on "Travel as 'A Fool's Paradise," in my essay "Travel and Travel Writing: An Historical Overview of Hodoeporics," Annali d'italianistica, 14 (1996), pp. 13-18. See also E. S. Bates, Touring in 1600 (London: Constable, 1911; rpt. London: Century, 1987); Attilio Brilli, Quando viaggiare era un'arte (Bologna: Il Mulino, 1995); Antoni Maczak, Travel in early Modern Europe (Cambridge: Polity Press, 1995); Jeremy Black, The British Abroad: The Grand Tour in the Eighteenth Century (New York: St. Martin's Press, 1992). 
3. Piero Camporesi's introduction to his edition of the Libro dei vagabondi: lo "Speculum cerretanorum" di Teseo Pini, "Il vagabondo" di Rafaele Frianoro e altri testi di "furfanteria" (Turin: Einaudi, 1973).

4. See the Dictionnaire de théologie catholique, vol. II, pt. 2, col. 2513-2518.

5. De haeresibus, in Migne, Patrologia latina, xii, col. 1197-1198.

6. De opere monachorum (xxviii), in Migne, Op. cit., pp. 575-576.

7. "Monachi qui sine licentia episcopi vagantur, ad propria loca redire coguntur" (Decretum Gratiani, quoted in Camporesi, p. xii). Piero Camporesi calls it a tradition of crime ("impianto a delinquere"): small groups of followers of this religio mendicans, fraternities of beggars, bands of almsmen, often alternating their soliciting with periods of orgy and debauchery.

8. In a letter to Irish bishops, Pope John XXII mentioned the need to take serious disciplinary measures against "nonullos fratres mendicantes et alios clericos subvertentes populum Ibernie a devotione regis et persuadentes eis mala facere" (quoted by L. Fumi, Eretici e ribelli nell'Umbria [Todi: Atanor, s.d.], p. 13).

9. La civillisation de l'Occident médiéval (Paris: Arthaud, 1965), p. 172. See also Marjorie Rowling, Everyday Life of Medieval Travellers (New York: Dorset Press, 1971).

10. In Poeti del Duecento, ed. G. Contini (Milan-Naples: Ricciardi, 1960), II, p. 288.

11. Piero Camporesi, Il libro dei vagabondi, pp. xxiii-xxiv.

12. "De utilitate colloquiorum" in Opera omnia (Amsterdam: North Holland, 1972), I, iii, p. 742.

13. Ralph Waldo Emerson, "On Self-Reliance," 2-3.

14. Ming Liaotse, a cultured vagabond who lives a happy, carefree, almost contemplative life, is glorified in sixteenth-century China by T'u Lung: "I go forth with a friend who loves the mountain haze. [...] And we two go begging through cities and through hamlets, at vermilion gates and at white mansions, before taoist temples and monks' huts. [...] The tone of our begging is humble, but not tragic. If people give, we leave them, and if peole don't give, we also leave them; the whole object being merely to forestall hunger. If some people are rude, we take it with a bow. [...] We travel without a destination and stop wherever we find ourselves, and we go very slowly, ... and when we are enchanted with the springs and white rocks and water fowls and mountain birds, we choose a spot on a river islet and sit on a rock, looking at the distance. [...] If it is willed that our days are numbered, then there our journey ends. But if we escape it, then we go on as before ("The Travels of Ming Liaotse" in Lin Yutang, The Importance of Living [New York: Reynal \& Hitchcock, 1937], pp. 341-342).

15. Juan A. Ortega y Medina, El conflicto anglo-español por el dominio oceánico (siglos XVI y XVII) (Málaga: Editorial Alcanzara, 1992), p. 71.

16. Didier Souillier, Le roman picaresque (Paris: Presses Universitaires de France, 1980).

17. Cervantes, "La ilustre fregona," in Novelas ejemplares, ed. H. Sieber (Madrid: Cátedra, 1994), II, p. 141. 
18. "... members of the organized gangs which infest mountainous districts of Italy, Sicily, Spain, Greece, and Turkey" (O.E.D., s.v. "bandit"). The Encyclopedia Britannica (1911) showed that in the 1897-1898 criminality in Sicily was running more than ten times higher than in northern Italy.

19. Antonio De Beatis, Die Reise des Kardinals Luigi d'Aragona durch Deutschland, die Nederlande, Frankreich und Oberitalien, 1517-1518, ed. L. Pastor (Freiburg im Breisgau: Herder, 1905), p. 108.

20. Thomas Coryate, Crudities ... [1611] (Glasgow: J. MacLehose, 1905), 2 vols, II, p. 308.

21. Jean-Jacques Bouchard, "Voyage de Paris à Rome," and "Voyage dans le royaume de Naples" in Oeuvres, ed. E. Kanceff (Turin: Giappichelli, 1977), I, p. 47. It is not without importance to consider the daily impact that cruel punishments had on the psyche of individuals. It is absolutely necessary to understand that the sensitivity of our medieval and Renaissance writers is extremely different from ours: the daily occurrence of corpses hanging at the city gates or criminals' heads stuck along a bridge must have had a dulling influence on their perception of human suffering.

22. E. Motta, "Un'ambasciata veneta attraverso il Gottardo nel 1626," Bolletino storico della Svizzera italiana (1897), p. 75.

23. Un mercante di Milano in Europa: diario di viaggio del primo Cinquecento, ed. L. Monga (Milan: Edizioni Universitarie Jaca, 1985), p. 175. Orazio Busino, on the other hand, near Vitoria, seeing empty gallows outside the city, underscores, tongue in cheek, the ambiguity of the scene: "o che siano tutti huomini da bene oppure ciascheduno pessimo." See my forthcoming study Un ambasciatore veneziano nell'Europa del primo Seicento: $i$ diari di Pietro Conrarini (1606-1623) (Moncalieri: CIRVI).

24. Charles Estienne, Le guide des chemins de France [1553], ed. J. Bonnerot (Paris: Champion, 1936): "passage perilleux au milieu de la forest" (p. 25); “dangereux passage" (p. 37); "iadis faisoit dangereux passer" (p. 53); "passage perilleux" (p. 85); "ancienne briganderie" (p. 94); "dangereux passage" (p. 104); "un tailliz, lieu autresfois dangereux" (p. 124); "brigandage" (p. 157), etc.

25. Sebastiano Locatelli, Viaggio di Francia: costumi e qualità di quei paesi (1664-1665), ed. Luigi Monga (Moncalieri: CIRVI, 1990), p. 190.

26. Thomas Hoby, The Travels and Life of Sir Thomas Hoby, ed. Powell (London: Camden Miscellany, 1902), p. 17.

27. Fynes Moryson, Shakespeare's Europe: A Survey of the Condition of Europe at the End of the 16th Century, Being Unpublished Chapters of Fynes Moryson's Itinerary (1617), ed. Charles Hughes (New York: Blom, 1967 [rpt. London 1903 edition]).

28. From the journals of the Venetian ambassadors to Spain (Tiepolo, Vendramin, Contarini, et al.), we know that a $10 \%$ tax was levied on everything of value the traveller was carrying when entering one of the kingdoms in which Spain was divided. Half the price of the gold chain Philip II gave Antonio Tiepolo was paid back in taxes by the time Tiepolo had reached France! See Luigi Monga, Due ambasciatori veneziani nella Spagna di fine Cinquecento: i diari dei viaggi di Antonio Tiepolo (1571-1572) e di Francesco Vendramin (1592-1593) (Moncalieri: CIRVI, 1999). 
29. In a famous poem, "Romagna" (in Myricae), Giovanni Pascoli mentions, among the "great people" of his native land, a well-known gentleman/bandit of the eighteenth century, "il Passator cortese / re della strada, re della foresta" (II, 59-60).

30. Quoted in Roma-Capua, ed. D. Strepos (Rome: Autostrade, 1966), p. 140.

31. “... si diceva che la strada di Genoa a Milano non era troppo sicura di ladri” (p. 217). 70 years later, Francis Mortoft wrote about this area: "[At Matarana], and in other [places] as wee rid along, we tooke the mountanous People to be like Devils in the shape of Men. Every Poore fellow having his dagger by his side, and staring and swearing as if they were all Princes, and indeed counting themselves Princes of those Mountains, which when they see their oppertunity, they make nothing to inrich themselves by the spoyles of Passengers; where it was told to us by those who went with us ... that in that place where wee passed ... within few yeares there was as much gold and silver taken from Passengers by these Mountanous People as would load halfe a dozen Mules" ( Francis Mortoft: His Book, Being His Travels through France and Italy (1658-1659), ed. Malcolm Letts [London: The Hakluyt Society, 1925], pp. 44-45).

32. In January 1645, near Sermoneta, between Rome and Naples, John Evelyn noticed "a Towre built on a rock, kept by a small watch or Guard against the Banditi, who are very rife in these parts, daily robbing and killing the Passengers, as my Lord Banbury and his Company found to their cost, a little before" (pp. 317-318).

33. Mario Scaduto, "La strada e i primi gesuiti," Archivum historicum Societatis Iesu, XL (1971), pp. 337-339. Fr. Scaduto's essay deals also with Turkish pirates raiding the Italian coast and assaulting travellers who happen to take the scenic route. Another dangerous area was the road between Valencia and Barcelona (Un mercante di Milano, p. 148). While in Pisa, in July 1582, Montaigne states matter-of-factly, that "al 22 a l' alba arrivarono tre legni di corsari Turcheschi al lito vicino [probably near Marina di Pisa] e levarono via quindici o venti prigioni, pescatori e poveri pastori" (Michel de Montaigne, Journal de voyage, ed. F. Rigolot [Paris: Presses Universitaires de France, 1992]), p. 193.

34. "Giunto il povero paziente, vestito delle sole mutande, lo legano per le mani e piedi a quattro caviglie di ferro, come stava l'Apostolo Sant'Andrea sulla croce; poi, alzando il boia per tagli quella pesante ruota, lasciò caderla due volte ad infrangere in due parti il dritto braccio; lo stesso fece con l'altro, poi con le coscie e gambe, che furono in tutto otto colpi. Quando v'è grazia del re, gli dà un colpo di più sulla bocca dello stomaco, il quale lo fa morire in meno d'un'ora, grazia che non toccò a questo disgraziato. Poi, voltando in giù quel miserabile, misero sopra del suo sedere la ruota in piano e rivoltando le stronche braccia e gambe sopra di quella, legate tutte assieme, rivolraron la ruota allo insù e lo lasciarono così vivo a rimirare il cielo e a vivere fin tanto che lo spasimo veniva a dargli la morte" (Locatelli, p. 217).

35. S. Locatelli, Viaggio di Francia, pp. 181-182.

36. Francesco Rucellai, Un'ambasiata: diario dell'abate Francesco Rucellai, ed. G. TempleLeader and G. Marcotti (Florence: G. Barbera, 1884), p. 272.

37. Francesco Rucellai, Op. cit., pp. 12, 54. 
38. The danger of Turkish pirates deserves a special treatment, for there was a constant fear of this kind of encounters along the coast of the Mediterranean. Thomas Hoby notes, almost parenthetically, on January 11,1550, near Monte Circeo, hearing the rumor that there were "Moores and Turks with their foistes and other vessels to take the passinger vesselles that goo betwixt Roome and Naples. And we were afterward enformed that this time there laye IX, so that yf we had cum bye yt by day, as we did by night, we had bine all taken slaves" (Thomas Hoby, Op. cit., p. 27).

39. O. Busino, 16 January 1618, Op. cit.

40. Jean Bonnerot, "Esquisse de la vie des routes au $\mathrm{XVI}^{\mathrm{e}}$ siècle," Revue des Questions Historiques, LIX, 3 (1931), pp. 62-63. 